Long-Acting Reversible Contraception (Clinical Guidance CG30). October 2005. http://www.nice.org.uk/Guidance/CG30/ Guidance/pdf/English [Accessed 8 January 2009].

3 Every Child Matters: Change for Children. Teenage Pregnancy: Accelerating the Strategy to 2010 (DFES-03905-2006). 2006. http://www.everychildmatters.gov.uk/health/teenagepregnancy/ about/ [Accessed 8 January 2009].

4 Heart of Birmingham Teaching PCT. BRASH: Birmingham Reproductive and Sexual Health Service website. http://www.brash.nhs.uk [Accessed 8 January 2009].
5 Chambers J. Sexual health needs assessment. Sex in the City Report: Commissioning and Redesign of Pan Birmingham Sexual Health Services. 2008. http://www.hobtpct.nhs.uk/ docs/board/pec/2008/200806 [Accessed 8 January 2009].

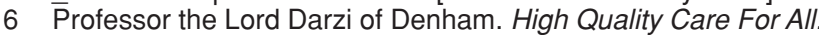
NHS Next Stage Review: Final Report. http://www.nhs.uk/ ournhs [Accessed 8 January 2009].

7 Davis A, Hill C, Rosewarne L. SANA: Sex And New Attitudes: Results of 13 Focus Group Reviews. Birmingham Reproductive and Sexual Health (BRASH), 2009 (unpublished data).

\title{
British Menopause Society
}

What service do you offer?

Information on all aspects of postreproductive health: as simple as that. This is so woefully lacking - or contradictory - that there is a real need for accurate interpretation of data and reports; good, informative fact sheets, via our own website (www.thebms.org. uk) and comprehensive education via meetings, seminars and conferences.

\section{How are you organised?}

The British Menopause Society (BMS) is based in Marlow in Buckinghamshire, but serves the whole of the UK. We were established in 1989 and currently have almost 900 members. The charity is run by three part-time members of staff: a chief executive officer, a membership and conferences manager and an administrator.

\section{What's been your biggest triumph over the years?}

Consistently providing authentic, accurate information to those who need it. Our meetings are consistently rated as 'very good' or 'excellent' and despite several years in decline, our membership numbers have now gradually started to climb again.

What's been your biggest problem? Income! As always! We need to maintain and grow membership and increase attendance at our regional women's health meetings and annual symposium in order to generate income for the BMS. Our 900 members value the service we provide but with 45000 general practitioners (GPs) alone out there, we need to capture the interest of more of you!

J Fam Plann Reprod Health Care 2009; 35(2): 126

\section{Cambridge, UK}

Susan Quilliam, BA, Cert Ed, MNLP, Freelance Writer, Broadcaster and Agony Aunt

Correspondence to: Ms Susan Quilliam. E-mail: susan@susanquilliam.com

\section{FURTHER INFORMATION}

Who: British Menopause Society

Where: 4-6 Eton Place, Marlow,

Bucks SL7 2QA, UK

Contact: +44 (0) 1628890199 (telephone) +44 (0) 1628474042 (fax)

E-mail: admin@thebms.org.uk

Website: www.thebms.org.uk

\section{Describe a typical client/user}

Typically our members were largely made up of obstetrics and gynaecology consultants and GPs. However, there has been a marked increase in nurse members as GPs pass menopausal issues on. We are attracting more members now from other health care professions including nutritionists, physiotherapists, and psychiatrists even a medical librarian.

We take many calls from women, often asking advice prior to visiting their GP. We pass these to our sister charity, Women's Health Concern (www.womens-health-concern.org), who operate a telephone and e-mail helpline and an excellent easy-tonavigate website.

\section{What are the top three problems clients present?}

Confusion! Confusion! Confusion! What to advise? So many women are told when presenting with symptoms: "Put up with it. Menopause won't kill you, but HRT will". That's slightly unfair, but with reports racing around about increased risks of breast cancer, stroke and endometrial cancer, to name but three, patients and doctors alike are at best confused and at worst aggressively anti-HRT.

But menopause isn't just about HRT. Menopause heralds the changes in the body that increase the risks of women developing all sorts of conditions. And with increasing life expectancy, Western women can now expect to live a third of their lives - or half their adult life - post-menopausal.

\section{How do you get clients?}

We recruit new members at regional women's health meetings, special skills meetings and at our annual symposium. This year we are targeting overseas members as the BMS is hosting the European Menopause and Andropause Society (EMAS) Congress. This takes place on 16-20 May 2009 at the ExCel Centre in London's Docklands. The EMAS scientific planning committee has put together an excellent and comprehensive programme and there are special BMS members' registration rates (see www.emasonline.org).

\section{Do you give comments to the press? What are the key issues you comment on?}

Yes, on a very regular basis. Often new 'Shock! Horror!' articles regarding the side effects of HRT, but increasingly general questions about postreproductive health, which is encouraging. The Daily Telegraph produced a 16-page supplement in conjunction with the BMS - it was hugely satisfying to see accurate copy in a national newspaper!

What are your most exciting plans/biggest hopes for the future? EMAS - we are expecting more than 1500 delegates over 4 days from the UK and all over Europe.

\section{What's the biggest worry for your organisation?}

Survival. With the economic climate we're currently operating in, all charities are going to feel the pinch over the next year or so and the BMS covers an area of health that doesn't really capture people's hearts and minds. Menopause is, sadly, just not as emotive as cancer and heart disease!

\section{Editor's note}

This is the third of a series of occasional articles on key health organisations worldwide. The Journal would be pleased to hear from other organisations, particularly those based outside the UK, which would like to be similarly profiled. 